\title{
MARKET ORIENTATION AND SNS ADOPTION FOR MARKETING PURPOSES IN HOSPITALITY MICROENTERPRISES
}

A. Herrero*, H. San Martín and J. Collado

University of Cantabria

* Corresponding author: Department of Business Administration, University of

Cantabria, Av. de los Castros, s/n - 39005, Santander, Spain. Tel.: +34.942.20.39.08;

Fax: +34.942.20.18.90

E-mail addresses: herreroa@unican.es (A. Herrero), smartinh@unican.es (H. San

Martín), colladoj@unican.es (J. Collado)

Acknowledgments: This research was supported by the Dirección General de Turismo del Gobierno de Cantabria (Spain). 


\section{VITAE}

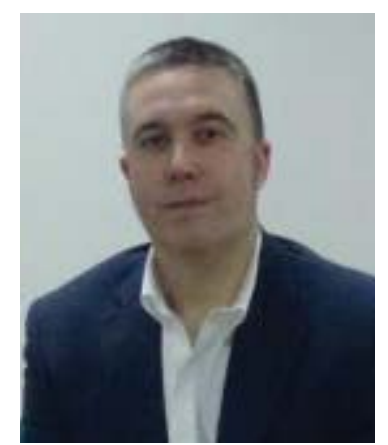

Ángel Herrero is an associate professor of marketing at the University of Cantabria (Spain) (Email herreroa@unican.es). His main areas of work are international marketing, consumer behavior, and new technologies adoption. His research has led to the publication of about 25 scientific papers in renowned journals such as Computers Human Behavior, Interacting with Computers, Electronic Commerce Research and Applications, Behavior and Information Technology, Tourism Management, International Journal of Hospitality Management, International Journal of Advertising, Journal of Risk Research, Journal of Business Ethics, The Service Industries Journal, and International Marketing Review. He is author of five chapters published in collective books.

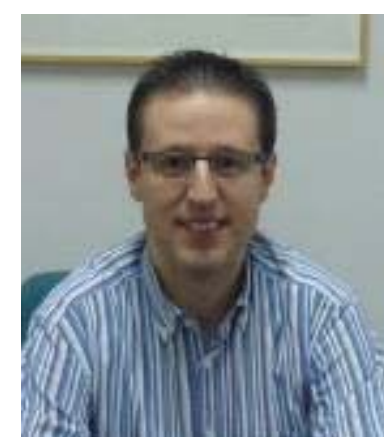

Héctor San Martín is an associate professor of marketing at the University of Cantabria (Spain) (Email smatinh@unican.es). His main lines of work are tourism marketing and consumer behavior. His research so far has led to the publication of over 20 scientific papers in international journals such as Annals of Tourism Research, Current Issues in Tourism, International Journal of Contemporary Hospitality Management, International Journal of Hospitality Management, Journal of Risk Research, Tourism Management, and International Marketing Review. He is author of three chapters published in collective books. 




Jesús Collado is a Bachelor BA in Business Administration and Ph.D. at Cantabria University, where he is Associate Professor in the Faculty of Economics, Cantabria University (Email colladoj@unican.es). He is the author and co-author of several publications in Services Industries Journal, Industrial Marketing Management, Tourism Management, and other Marketing journals. His research experience focuses on distribution channels, service marketing and tourism satisfaction. 


\title{
MARKET ORIENTATION AND SNS ADOPTION FOR MARKETING PURPOSES IN HOSPITALITY MICROENTERPRISES
}

\begin{abstract}
In a nowadays context where the social network sites (SNS) have a widespread use among users and enterprises, this paper aims to analyze the factors determining the adoption of SNS for marketing purposes by hospitality microenterprises. With this objective, our study develops a model that includes: 1) the two pillars of market orientation for companies (i.e. consumer orientation and competitor orientation); and 2) the factors of the widely used Unified Theory of Acceptance and Use of Technology (UTAUT): performance expectancy, effort expectancy, social influence, and facilitating conditions. The results from a sample of 200 hospitality microenterprises in a region of Spain show that the intention to use SNS for marketing purposes (in particular, business communication) is mainly determined by the expectancies of managers or owners about the performance and effort in the use of the technology, and by the social influence generated by users and professionals in the sector. Additionally, in contrast to competitor orientation, customer orientation has a positive influence on performance expectancy and social influence.
\end{abstract}

Keywords: Social network sites, market orientation, UTAUT, intention to use, microenterprises 


\section{INTRODUCTION}

Technology and digital marketing are changing the way of doing business, moving from traditional to digital focus (Kotler, Kartajaya \& Setiawan, 2016). In this context, the emergence of social media such as social networks sites, review websites, photo-sharing websites, microblogs, or video-sharing websites has revolutionized the use of the internet as a communication channel in business, because they represent a great opportunity for interactions between consumers and between providers and users (Herrero, San Martín, \& Hernandez, 2015). According to Parveen, Jaafar \& Ainin (2015), social media is growing as an important strategic tool among organizations that enables to build relationships with the online public, a primary characteristic of a consumer-oriented business. The influence of social media, and particularly the effect of social networks sites (SNS), has been especially important in the tourism and hospitality industry (Kwok \& Yu, 2013; Law, Buhalis \& Cobanoglu, 2014; Leung, Law, Van Hoof, \& Buhalis, 2013; Xiang \& Gretzel, 2010) where individuals tend to share experiences with other people through publishing photos, videos, or opinions on the internet (Buhalis \& Law, 2008).

SNS, which have become one of Web 2.0's most used services during the last decade (Fang, 2014), are web applications that allow individuals to publish comments and multimedia content through a public or semi-public profile within a bounded system (Boyd \& Ellison, 2008), thereby making them available to their contact groups (Chen, Tang, Wu, \& Jheng, 2014). A paradigmatic example of a social network site is Facebook, the market leader among all social media with more than 1,550 million users around the world in 2016 (Statista, 2016). Its increasing penetration among consumers has made social network sites an essential channel for business communication, with an increasing number of enterprises creating their own corporate pages in SNS in order to better communicate their offers to the market and manage relationships with their customers. In addition, SNS give place to a great amount of data and information about consumers (Fernandes, Bello \& Castela, 2016), which requires businesses to be more nimble and reactive (Hofacker \& Belanche, 2016) in their marketing management. In a similar 
way, in the specific field of tourism and hospitality, Palacios-Marques et. al (2015) point out that the introduction of online social networks is a key aspect to give a better response to consumer needs.

This phenomenon has attracted a great deal of attention from both practitioners and academics in many disciplines ( $\mathrm{Fu}, \mathrm{Ju}, \&$ Hsu, 2015), engendering a productive line of research (Van Osch \& Coursaris, 2014). Most studies have focused on consumer behavior and, more concretely, on their responses to communication and marketing campaigns based on SNS; however, there are few works about the drivers of the adoption of SNS in enterprises (Van Osch \& Coursaris, 2014; Martins, Gonçalves, Pereira, Oliveira, \& Pérez, 2014). Therefore, this paper intends to analyze the most important variables determining the adoption of SNS as a communication tool by enterprises in the hospitality sector. To better understand this phenomenon, the study focuses particularly on the market orientation of enterprises, one of the key theoretical concepts in marketing literature during the last two decades (Grinstein 2008a, 2008b; Hult, Hurley, \& Knight, 2004; Jaworski \& Kohli, 1993; Verhees \& Meulenberg, 2004).

Previous research has failed to integrate internet and market orientation (Celuch \& Murphy, 2010). Specifically, Tsiotsou and Vlachopoulou (2011) point out the scarce amount of literature available on the influence of market orientation on e-marketing use in services. With the internet's ability to facilitate communication and transactions with both internal and external stakeholders, and market orientation's focus on obtaining, sharing, and responding to information associated with customers and competitors, it makes conceptual and managerial sense to explore the "marriage" of these two areas. Additionally, the few studies about the adoption of SNS by firms have focused on bigger enterprises (Martins et al., 2014), but much less research has been done regarding the adoption of this tool by small companies. This may be because small organizations are not usually considered very proactive in adopting e-commerce technologies to support their business activities (Al-Qirim, 2007). In this sense, Polo, Frías and Rodríguez (2011) point out that, despite the importance of small-sized firms, the knowledge 
about decision-making processes in microenterprises is very limited, especially in the field of hospitality.

In order to fill this gap in the literature, this paper specifically focuses on the adoption of SNS by microenterprises (defined as enterprises with less than 10 employees and an income below 2 million euros by the European Commission (2003)) in the hospitality sector, with special attention paid to the manager's decision-making process. Given that the organizational structure is minimal in hospitality microenterprises, which have habitually a single manager/owner and a few employees mainly devoted to work related to keeping rooms and reception, we consider that it is the owner or manager who makes the decisions on innovation and marketing (Lee \& Runge, 2001; Herrero, Collado, \& García de los Salmones, 2013). Additionally, microenterprises have no functional departments to coordinate or disseminate information (Verhees \& Meulenberg, 2004), so this paper only takes into consideration the two dimensions theoretically proposed by Narver and Slater (1990) which are especially applicable to hospitality microenterprises (Chen \& Myagmarsuren, 2013): customer orientation and competitor orientation.

Consistent with this focus, the paper uses the Unified Theory of Acceptance and Use of Technology (UTAUT) established by Venkatesh, Morris, Davis, and Davis (2003) as its framework. The reasons for the use of this model are the following. First, it is explicitly aimed at explaining the adoption of technologies by individual decision-makers, as is the case in the use of SNS for communication in microenterprises. Second, it has a global and integrative approach, as it incorporates the main explanatory variables of previous theoretical models about technology acceptance and use. Third, it is highly parsimonious, in contrast to other models, as it only includes four explanatory variables. Fourth, it has proven to be a successful model for studying technology acceptance and use in a variety of contexts (Venkatesh, Thong, \& Xu, 2012).

With this in mind, our study aims to make two main contributions to the hospitality research: on the one hand, we try to explain the role of market orientation in the use of SNS by 
microenterprises for marketing purposes and, more concretely, business communication. On the other hand, we provide empirical evidence on how the SNS adoption by managers or owners of microenterprises is influenced by the basic explanatory variables from the UTAUT.

\section{BACKGROUND}

\subsection{UTAUT and SNS as a Communication Tool in Hospitality Microenterprises}

UTAUT (Venkatesh et al., 2003) is a global and integrative model developed to explain the adoption of technologies by individual decision-makers. Accordingly, given that the adoption of new technologies in microenterprises is usually an individual decision of the manager (Lee \& Runge, 2001; Herrero et al., 2013), we have used this theory as a framework. On the basis of an exhaustive revision of the diverse explanatory variables included on previous theoretical models, the UTAUT identifies the following four key drivers in the adoption of technologies or information systems (Venkatesh et al., 2003). First, performance expectancy refers to the degree to which an individual believes that using the technology will help him or her improve the performance of a task or piece of work. Second, effort expectancy is the degree of ease associated with the use of the technology. Third, social influence is considered the degree to which an individual perceives that important people believe he or she should use the technology. Finally, facilitating conditions refer to degree to which an individual believes that an organizational and technical infrastructure exists to support the use of the technology.

UTAUT considers two direct determinants of technology acceptance: (1) the intention to use the system, and (2) the facilitating conditions. On the one hand, Venkatesh et al. (2003) establish that the intention to use a technology is the main indicator of its effective use, and define it as a firm purpose to develop a behavior in the future. On the other hand, UTAUT also includes the facilitating conditions perceived by the individual as a direct determinant of technology use, with the logic that this factor reflects environmental limits or incentives for the individual's behavior (Venkatesh et al., 2003). Additionally, three variables are direct antecedents of the 
intention to use a technology: (1) performance expectancy, (2) effort expectancy, and (3) social influence associated with the use of the system.

UTAUT has been extensively used to analyze the use of technologies by individuals both in organizational settings (Al-Gahtani, Hubona, \& Wang, 2007; Eckhardt, Laumer, \& Weitzel, 2009) and personal contexts (AbuShanab \& Pearson, 2007; Wang \& Wang, 2010). In the specific field of tourism, this theoretical framework has been used to explain users' acceptance of different technologies (San Martín \& Herrero, 2012; Escobar-Rodríguez \& Carvajal-Trujillo, 2014). Overall, the empirical evidence obtained in the above-mentioned studies supports the validity of UTAUT to study the adoption of new technologies in tourism, and confirm the significant effect of performance expectancy, effort expectancy and social influence on the adoption of new technologies by users.

Accordingly, this study postulates that the use of SNS as a communication tool by hospitality microenterprises is significantly influenced by: (1) the performance expected by managers in the use of SNS, (2) the effort perceived by managers in its use, and (3) the social influence exerted by users and managers on the use of SNS in microenterprises. Therefore, we propose the following hypotheses regarding the adoption of SNS as a communication tool by microenterprises in the sector under investigation:

Hypothesis 1: The performance expectancy perceived in the use of SNS as a communication tool positively affects the manager's intention to use it.

Hypothesis 2: The effort expectancy perceived in the use of SNS as a communication tool positively affects the manager's intention to use it.

Hypothesis 3: The social influence regarding the use of SNS as a communication tool positively affects the manager's intention to use it. 
With regard to the effect of facilitating conditions on the adoption of information technologies, the available empirical evidence in this regard is contradictory. Some studies based on UTAUT do not include this factor as an explanatory variable (Lu, Yao, \& Yu, 2005; Van Raaij \& Schepers, 2008; Wang, Wu, \& Wang, 2009), while others propose a direct influence of the facilitating conditions on acceptance intention (Venkatesh et al., 2012). The latter approach is consistent with the Theory of Planned Behavior (Ajzen, 1991) and the Decomposed Theory of Planned Behavior (Taylor \& Todd, 1995), which include perceived behavioral control (analogous to facilitating conditions) as a direct antecedent of behavioral intention. Accordingly, the variable "facilitating conditions" reflects the perceptions of the individual, and not the actual facilitators and limitations to develop the behavior, so it affects the cognitive processes that generate the intention and not necessarily the behavior (Venkatesh et al., 2012). In line with this more recent approach, it is postulated that the manager's perception of the facilitating conditions available for the microenterprise determines his/her intention to use SNS as a communication tool in the hospitality sector. Therefore, we propose:

Hypothesis 4: The facilitating conditions perceived in the use of SNS as a communication tool positively affects the manager's intention to use it.

\subsection{Market Orientation, Customer Orientation and Competitor Orientation}

Market orientation has been one of the key theoretical concepts in marketing literature during the last two decades, with two main and clearly distinct conceptual approaches. On the one hand, Narver and Slater (1990, p. 21) adopt a cultural perspective and define market orientation as "the organization culture that most effectively and efficiently creates the necessary behaviors for the creation of superior value for buyers and, thus, continuous superior performance for the business". These authors propose three different market orientation dimensions: customer orientation, competitor orientation and interfunctional coordination. On the other hand, Kohli 
and Jaworski (1990) present a perspective of market orientation based on information, highlighting a market intelligence phase based on customers' current and future needs, a process of dissemination of generated intelligence in the organization, and a process of response to the market. The two approaches show the need to consider consumers' desires and needs and competitors' strategies in the definition of commercial policies, but each one adopts a different focus.

Both conceptualizations of market orientation have been mainly developed for large and medium-sized enterprises, with a departmental organizational structure that requires "interfunctional coordination" and "information dissemination" in the organization, and only to a lesser extent for small firms (Herrero, Collado \& Garcia de los Salmones, 2013; Verhees \& Meulenberg, 2004). However, this approach is not suited to microenterprises, in which management is mainly individual and there are no functional departments to coordinate or among which to disseminate information (Verhees \& Meulenberg, 2004). Accordingly, this research adopts the conceptualization of market orientation proposed by Narver and Slater (1990) but, following the approach of Chen and Myagmarsuren (2013) in the specific field of tourism, we only take into consideration the two dimensions applicable to microenterprises: customer orientation and competitor orientation. Consistent with this approach, customer orientation emphasizes the importance of sufficiently understanding target customers, and competitor orientation focuses on understanding competitors' strengths and weaknesses and monitoring their activities (Narver \& Slater, 1990; Chen and Myagmarsuren, 2013).

Different authors have suggested that market orientation is an antecedent of innovative behavior in an organization because it implies doing something new or different in response to market conditions (Grinstein, 2008a, 2008b; Herrero et al., 2013; Hult et al., 2004). In this context, Jímenez-Jiménez, Sanz-Valle and Hernández-Espallardo (2008) observe that market orientation exerts a direct effect on a firm's innovation, including the adoption of new processes and managerial systems. Similarly, according to Nguyen (2007) and Polo, Frías and Rodríguez (2013), the level of market orientation in a firm positively influences the use of new 
technologies. In the specific field of microenterprises, Herrero et al. (2013) observe that the manager's market orientation indirectly influences the adoption of management technologies through its effect on personal innovativeness. In this sense, given that market orientation focuses on understanding customers and competitors in order to create superior value for buyers (Narver \& Slater, 1990), it is logical to expect that it has a direct influence on the implementation of new technologies in the field of marketing (Polo et al., 2013). The study by Tsiotsou and Vlachopoulou (2011) confirms the positive effect of market orientation on emarketing use in enterprises, which includes the use of SNS. Consequently, given that tourists extensively use SNS in the purchasing process, a manager's intention to use SNS as a communication tool in his/her enterprise will be higher if she/he has a high market orientation. Therefore, in order to isolate the effects of customer orientation and competitor orientation, we propose the following hypotheses:

Hypothesis 5: The manager's customer orientation has a positive influence on his/her intention to use SNS as a communication tool.

Hypothesis 6: The manager's competitor orientation has a positive influence on his/her intention to use SNS as a communication tool.

Nguyen (2007) also finds evidence supporting the proposal that the level of market orientation in a firm positively influences the usefulness perceived in a specific technology (e.g. the internet), a variable which is equivalent to performance expectancy according to Venkatesh et al. (2003). This result suggests that a higher market orientation can lead managers to the perception of a higher performance expectancy regarding the use of a specific technology, as they are more aware of the importance of these applications for consumers and of their use by competitors. In this way, managers will perceive a higher performance expectancy regarding the use of SNS as a communication tool if they have a high market orientation. Therefore, we 
propose the following research hypotheses for the separate effects of customer orientation and competitor orientation:

Hypothesis 7: The manager's customer orientation has a positive influence on the performance expectancy perceived regarding the use of SNS as a communication tool.

Hypothesis 8: The manager's competitor orientation has a positive influence on the performance expectancy perceived regarding the use of SNS as a communication tool.

Finally, market orientation reflects a tendency to act according to customer needs and competitors' strategies (Narver \& Slater, 1990). Accordingly, market orientation will enhance manager awareness regarding the opinions of customers and competitors with respect to the use of a technology (Bartl, Fuller, Muhlbaccher, \& Ernst, 2012), which would lead to a higher subjective norm (D'Ambra, Rice, \& O'Connor, 1998), a variable equivalent to social influence (Venkatesh et al., 2003). In this context, given the widespread use of SNS by consumers and firms, these collectives would exert a positive social influence with regard to the use of SNS as a communication tool by microenterprises, which will be more intense the higher the manager's market orientation. Therefore, we propose the following research hypotheses:

Hypothesis 9: The manager's customer orientation exerts a positive social influence regarding the use of SNS as a communication tool.

Hypothesis 10: The manager's competitor orientation exerts a positive social influence regarding the use of SNS as a communication tool.

Figure 1 shows the theoretical model of our paper, including all research hypotheses. 
Figure 1. Theoretical model

\section{METHOD}

In order to test the hypotheses, we developed a quantitative research study based on a survey of owners and managers of hospitality microenterprises. In particular, in line with the criterion established by the European Commission (2003), the target population was defined as enterprises with less than 10 employees and an income below 2 million euros in the abovementioned sector. Data was collected using a personal questionnaire that included the following key information: (1) the demographic characteristics of the enterprise and the manager/owner; (2) the variables included in the original formulation of UTAUT (i.e. intention to use SNS as a communication tool, performance expectancy, effort expectancy, social influence, and facilitating conditions); and (3) the customer orientation and competitor orientation in the micro-enterprise. In the second section of the questionnaire, and with the purpose of contextualizing the phenomenon under investigation (i.e. SNS), we included a first question about the SNS used by the firm to promote the business, considering as possible options the most used social network sites in a business context: Facebook, Instagram, Twitter and YouTube. Subsequently, all the measurement scales were referred to SNS, including any of the above-mentioned alternatives.

The variables of the model were all measured using multi-attribute instruments (ten-point Likert scales) adapted from previous works, in order to assure content validity (see Appendix). The original work of Venkatesh et al. (2003) served to develop the measurement scales for the intention to use SNS and the main explanatory factors included in UTAUT. Customer orientation and competitor orientation were measured using the instruments developed by Chen and Myagmarsuren (2013) in the specific field of tourism.

In order to obtain the sample of hospitality microenterprises - and given that there was no reliable census - data was collected using a non-probabilistic sampling procedure. In particular, 
the survey was sent by email to 1,306 hospitality microenterprises in the Spanish region of Cantabria (list provided by the tourism authorities of the Government of this region).

Enterprises that did not complete the survey were contacted by telephone to obtain a response. Finally, the response rate was $15.3 \%$, obtaining a valid sample of 200 hospitality microenterprises during the period April-May 2014.

Table 1 summarizes the characteristics of the microenterprises included in the sample and the sociodemographic profile of the respondents. Regarding the size of the microenterprises in terms of workers, $54.0 \%$ are individual entrepreneurs, $32.5 \%$ have two to four employees and only $13.5 \%$ have between five and nine employees. Additionally, $75.3 \%$ have an annual income below 100,000 euros, and 15.9\% have an income between 100,001 and 200,000 euros, while only $8.8 \%$ of the microenterprises sampled have an annual income of over 200,000 euros. As expected, the sample is formed by very small enterprises, which fits perfectly with the profile of microenterprises. With regard to the accommodation typology, $61.0 \%$ are rural tourism accommodations, $16.5 \%$ are hotels, $11.0 \%$ are tourist apartments and $10.0 \%$ are hostels or bed $\&$ breakfasts.

Table 1. Profile of firms and respondents

\section{RESULTS}

First of all, descriptive statistics were calculated for all variables included in the research model, in order to obtain a general perspective of the data obtained in the empirical research (Table 2).

Table 2. Descriptive Statistics 
In order to test the research hypotheses, statistical analyses were conducted using the structural equation modeling (SEM) methodology, with the program EQS 6.1 for Windows. First, the psychometric properties of the measurement scales (i.e. reliability and validity) were tested using a confirmatory factor analysis (CFA). Next, the structural or causal model was estimated in order to test our research hypotheses.

\subsection{Estimation of the Measurement Model and CFA}

The results obtained for the goodness-of-fit indexes show a correct specification of the model. In particular, there are three main classes of fit criteria: measures of absolute fit, incremental fit, and parsimonious fit (Hair et al., 2010). In this case, we use the statistics given by EQS 6.1, widely used in the SEM literature (Hair, Anderson, Tatham, \& Black, 2010): Bentler-Bonett normed fit index (BBNFI), Bentler-Bonett non-normed fit index (BBNNFI) and root mean square error of approximation (RMSEA) for the measurement of overall model fit; incremental fit index (IFI) and comparative fit index (CFI) as measures of incremental fit; and normed $\chi 2$ for the measurement of the parsimony of the model. The results summarized in Table 3 confirm that the BBNFI, BBNNFI, IFI, and CFI statistics exceed the recommended minimum value of 0.9. Besides these, RMSEA is located within the maximum limit of 0.08 , and normed $\chi^{2}$ takes a value clearly under the recommended value of 3.0 (Hair et al., 2010).

Table 3. Confirmatory Factor Analysis

Reliability of measurement scales is evaluated taking as reference the following indicators:

Cronbach's alpha, composite reliability and AVE coefficients (Bagozzi \& Yi, 1988). The values of these statistics are, in every case, clearly above the required minimum values of 0.7 and 0.5 respectively (Hair et al., 2010; Nunally, 1978), which supports inner reliability of the constructs 
proposed in the model (Table 3). The convergent validity of the scales is also confirmed (Table 3), since all items are significant to a confidence level of $95 \%$ and their standardized coefficients are higher than 0.5 (Steenkamp \& Van Trijp, 1991).

Discriminant validity of measurement scales is tested following the procedure proposed by Fornell and Larcker (1981). This method provides wide support for the discriminant validity of the scales used in this research, given that the squared correlation between pairs of constructs are lower than the average variance extracted of each construct (Table 4) in all the cases except one (effort expectancy - facilitating conditions). Given the results obtained, there is reasonable support for the discriminant validity of the scales used in this research.

Table 4. Squared correlation between pairs of latent variables

\subsection{Estimation of the Hypothesized Structural Model}

Once the psychometric properties of the scales were examined, the causal model was estimated by using the robust maximum likelihood estimation procedure to avoid the potential problems related to the non-normality of data. The results obtained support, in the first place, the significant effect of most of the explanatory variables proposed in the UTAUT. More concretely, performance expectancy $(0.47, \mathrm{p}<0.01)$, effort expectancy $(0.25, \mathrm{p}<0.01)$ and social influence $(0.31, \mathrm{p}<0.01)$, as perceived by managers or owners, have a significant influence on the intention to use SNS as communication tool in microenterprises, supporting H1, H2 and H3. On the other hand, the facilitating conditions do not significantly influence the intention to use SNS as communication tool in microenterprises, so H4 is not supported.

With regard to customer orientation, it is observed that this exerts a positive and significant effect on performance expectancy $(0.17, \mathrm{p}<0.01)$ and social influence $(0.30, \mathrm{p}<0.01)$, but it does not significantly influence the intention to use SNS as a communication tool. These results support $\mathrm{H} 5$ and $\mathrm{H} 6$, but lead to the rejection of $\mathrm{H} 7$. In addition, competitor orientation does not 
significantly influence performance expectancy, social influence and the intention to use SNS as a communication tool, thus rejecting $\mathrm{H} 8, \mathrm{H} 9$ and $\mathrm{H} 10$. According to these results, customer orientation is the only dimension of market orientation that has a significant influence on the intention to use SNS as a communication tool in microenterprises, although it is exerted indirectly through its effect on performance expectancy and social influence.

Furthermore, the results obtained for the Lagrange multiplier test (LM test) suggest a direct effect between effort expectancy and performance expectancy not included in the theoretical model. This result is consistent with the technology acceptance model, which establishes a causal effect of perceived ease-of-use on perceived usefulness, two variables equivalent to effort expectancy and performance expectancy (Venkatesh et al., 2003). Given the theoretical support for this relationship and the results obtained for the LM test, it is reasonable to assume that performance expectancy in the adoption of SNS in microenterprises will be higher if decision makers perceive less effort in this new management approach.

Applying the model development approach (Hair et al., 2010), the original model is reformulated (Figure 2) to exclude the non-significant relationships, and to include the new causal effect suggested by the LM test. The goodness-of-fit indexes support the correct definition of the re-specified model presented (normed $\chi 2=2.25 ; \mathrm{BBNFI}=0.92 ; \mathrm{BBNNFI}=$ $0.95 ; \mathrm{CFI}=0.95 ; \mathrm{RMSEA}=0.08$ ), and that it explains more than reasonably the variance of the dependent variable $\left(\mathrm{R}^{2}=0.49\right)$.

Figure 2. Estimation of the re-specified model

\section{DISCUSSION}

\subsection{Theoretical Implications}


This research has relevant theoretical implications with regard to the use of social media in the hospitality industry. In the first place, this paper analyzes the acceptance of SNS for marketing purposes by hospitality enterprises, in contrast with most previous research that focuses on individual behavior in SNS (Martins et al., 2014; Van Osch \& Coursaris, 2014). In particular, our results provide a new understanding of the role of market orientation in the use of SNS as a communication tool by enterprises. This is a relevant contribution in itself, since previous studies have failed to integrate the research on market orientation and the adoption of the internet (Celuch \& Murphy, 2010; Tsiotsou \& Vlachopoulou, 2011). Thus, our paper establishes a new theoretical approach for the understanding of this phenomenon, which includes the effects of market orientation on the intention to use SNS as a communication tool.

Second, this paper considers the particularities of microenterprises, in which main decisions are usually taken by the manager or owner (Lee \& Runge, 2001; Herrero et al., 2013). Thus, this research contributes to filling a gap in the previous literature on market orientation (Polo et al., 2011) and SNS application to marketing (Martins et al., 2014), which focuses on bigger enterprises. In particular, the focus on microenterprises implies a revision of the market orientation framework, as these types of firms do not have functional departments to coordinate or among which to disseminate information (Verhees \& Meulenberg, 2004). Accordingly, and following the approach of Chen and Myagmarsuren (2013) in the specific field of tourism, this research only takes into consideration the two dimensions of market orientation applicable to microenterprises: customer orientation and competitor orientation.

Third, by isolating the independent effects of customer orientation and competitor orientation, the empirical evidence obtained shows that only customer orientation has a significant effect on the use of SNS as a communication tool by hospitality microenterprises, and that this influence is exerted indirectly through its effect on performance expectancy and social influence. Meanwhile, competitor orientation does not exert either a direct or an indirect influence on the manager's decision making. This implies that, in essence, the intention to use a technology for communication purposes in microenterprises is guided by the changing preferences and 
behaviors of customers, which demand a quick and effective response from enterprises to adapt to the new behaviors in the market.

Finally, the empirical evidence obtained in this research supports the relevance of the explanatory variables included in UTAUT to explain the intention to use SNS as a communication tool by hospitality enterprises. Specifically, our results show that performance expectancy, effort expectancy and social influence have a direct effect on the manager's intention to use. Moreover, the influence of customer orientation on the intention to use SNS as a communication tool in microenterprises is exerted indirectly through its effect on performance expectancy and social influence. However, no significant effect of facilitating conditions on intentions is found. This result is especially relevant from a theoretical perspective, as it is contradictory to the approach that considers that facilitating conditions have a direct effect on intentions (Venkatesh et al., 2012).

\subsection{Practical Implications}

The findings of this research also have important implications from a practical perspective, and specifically for the development of policies aimed at fostering the implementation of new technologies in microenterprises for communication purposes. First, our results can be useful for the design and development of campaigns focused on the modernization of management in hospitality microenterprises. Specifically, given that the performance expectancy perceived by managers is the main determinant of their intention to use SNS as a communication tool, these campaigns should focus on the advantages provided by these applications in marketing management. In particular, these initiatives should highlight the usefulness of SNS in communicating the business online and fostering customer loyalty by using this technology for interaction with users and, for example, improving customer service and service recovery (Buhalis \& Law, 2008). Additionally, SNS can also be used to facilitate electronic word-ofmouth, providing a platform controlled by the firm for the publication of user-generated content, which has been found in the literature to have an influence on other customers' behavior. 
Moreover, the initiatives aimed at fostering the implementation of new technologies (e.g. SNS) in microenterprises should also focus on decreasing the effort perceived by managers in this task. In this way, the implementation of SNS as a communication tool in small firms can be relatively easy, given the generalized use of these applications in private life. Specifically, as many managers are familiar with SNS as individual users, communication campaigns could highlight that the application of this technology in the enterprise requires less effort than other alternatives. Another interesting initiative to improve the effort expectancy in the use of SNS would be the development of courses and training aimed at increasing managers' knowledge and self-efficacy in the use of these applications. Finally, SNS firms (e.g. Facebook) can also foster the implementation of their platforms in microenterprises for marketing purposes by developing more user-friendly interfaces and analysis tools, which would lead managers to perceive SNS as easy to implement in their enterprises.

For their part, these campaigns should also serve to enhance the social influence with regard to the adoption of technology by hospitality microenterprises. If managers feel that public and private organizations are committed to fostering and supporting the use of technologies such as SNS in small firms, they will perceive that this behavior is socially approved, which will positively affect their decision to implement them. Moreover, if these initiatives are based on the experience and knowledge of opinion-leaders and reputed professionals in the tourism sector, the impact on social influence can be even higher, leading to a stronger disposition to implement the technology within the firm.

Finally, the results obtained regarding the role of customer orientation and competitor orientation on the intention to use SNS are also relevant from a practical and managerial perspective. According to our findings, it is particularly important to develop a culture of customer orientation among the managers of hospitality microenterprises, in order to enhance the use of SNS as a communication tool that allows these types of firms to be more attractive and persuasive in the market. Once SNS are implanted in the microenterprises, these technologies themselves will gradually strengthen the customer orientation of managers by 
allowing them, for example, to monitor word-of-mouth and give a better response to present and potential customers.

\subsection{Limitations and Further Research}

Two limitations of this study are related with the measurement of the dependent variable of our model (i.e., the intention to use SNS as a communication tool). On the one hand, it was subjectively measured by capturing the perceptions of managers in relation to their future decision-making processes. Although this approach has been widely used past research on technology adoption (Bartl et al., 2012), several authors (Venkatesh et al., 2003; Venkatesh et al., 2012) recommend considering the effective behavior of usage. On the other hand, it was not established a reference time point (for example, next 12 or 18 months) to contextualize the intention, so it could negatively affect the reliability of our scale. Therefore, future studies should jointly examine the intention to use the technology (with a reference time point) and the effective behavior of use in microenterprises. In addition, there are some doubts about the use of SEM with non-random samples; however, McDonald and Ho (2002) explain that this issue may not be critical for testing a structural model, as is the case in this study.

Secondly, this study only analyzes the positive effect of variables on the intention to use SNS, but it do not address the influence of factors that inhibit the intention. Poba-Nzaou et al. (2016) finds three challenges not explicitly identified in the academic literature on social media: lack of internal resources, conservative attitude of managers, and non-professional image and reputation of social media platforms. Future investigations may evaluate the effect of this factors in the model proposed.

Finally, the findings of this study raise several questions for future research in relation to the factors affecting the use of SNS for marketing purposes in microenterprises. Therefore, as previously mentioned, it would be interesting to analyze which attributes or advantages of SNS lead to a higher performance expectancy by managers (e.g. ease of contacting customers, the 
potential for interaction with them, or the management of user-generated content). Similarly, it would be necessary to examine which factors lead to a better effort expectancy (e.g. time, psychological stress, or technology self-efficacy) or which collectives generate a more relevant social influence with regard to the use of the technology (e.g. public institutions, other managers, or experts). Finally, more effort is needed to increase the knowledge of the influence of market orientation on the use of technologies in microenterprises for marketing purposes, considering other mediating variables.

\section{CONCLUSION}

This research provides a relevant contribution to the literature on technology adoption for marketing purposes in the case of microenterprises. Consistent with the UTAUT (Venkatesh et al. 2003), our results support the proposal that the intention to use SNS as a communication tool is determined by the performance expectancy, effort expectancy and social influence perceived by the owner or manager. With regard to the effect of market orientation, according to the approach of Chen and Myagmarsuren (2013) in the specific field of tourism, customer orientation and competitor orientation are studied as separated explanatory variables, and we found that the adoption of technologies for management is indirectly influenced by the former but not by the latter. Specifically, our results show that performance expectancy and social influence with regard to the use of SNS as a communication tool are determined by customer orientation but not by competitor orientation. This implies that the managers' beliefs about a technology (e.g. the intention to use SNS as a communication tool) are mainly guided by their perceptions of customer needs and preferences referring to that technology. Accordingly, customer orientation would be the more relevant dimension of market orientation in microenterprises to explain the acceptance of new technologies for management in hospitality enterprises. 


\section{APPENDIX Measurement Scales}

\section{Intention to use SNS as a communication tool}

INT1 - I intend to use SNS to communicate my business

INT2 - I will probably use SNS to communicate my business

INT3 - I am decided to use SNS to communicate my business

\section{Performance expectancy}

PE1 - The use of SNS is very useful in communicating my business

PE2 - The use of SNS enables me to communicate my business more quickly

PE3 - The use of SNS increases my efficiency in communicating my business

PE4 - The use of SNS improves the performance of communicating my business

\section{Effort expectancy}

EE1 - The use of SNS to communicate my business is simple to me

EE2 - The use of SNS to communicate my business is an activity in which I consider myself

skillful

EE3 - The use of SNS to communicate my business is easy for me

EE4 - The use of SNS to communicate my business implies little effort for me 


\section{Social influence}

SI1 - The professionals whose opinions I value think that SNS are useful in communicating my business

SI2 - People who are important to me agree that I should use SNS to communicate my business

SI3 - Generally, the sector supports the use of SNS to communicate my business

\section{Facilitating conditions}

FC1 - I have the resources necessary to use SNS to communicate my business

FC2 - I have the knowledge necessary to use SNS to communicate my business

FC3 - I feel comfortable using SNS to communicate my business

FC4 - I have no problems using SNS to communicate my business

\section{Customer orientation}

CUO1 - Our enterprise often emphasizes the need to be customer-oriented

CUO2 - We regularly measure customer satisfaction

CUO3 - We spend a great deal of effort trying to understand customer needs

CUO4 - We do whatever it takes to create value for our customers

\section{Competitor orientation}

COO1 - We regularly study competitors' commercial strategies

$\mathrm{COO} 2$ - We respond quickly to our competitors' actions

COO3 - We regularly evaluate competitors' strengths and weaknesses 
COO4 - We take into account information about our competitors to develop our commercial actions 


\section{REFERENCES}

Abushanab, E., \& Pearson, J.M. (2007). Internet banking in Jordan: The unified theory of acceptance and use of technology (UTAUT) perspective. Journal of Systems and Information Technology, 9, 78-97.

Ajzen, I. (1991). The theory of planned behavior. Organizational Behavior and Human Decision Processes, 50, 179-211.

Al-Gahtani, S.S., Hubona, G.S., \& Wang, J. (2007). Information Technology (IT) in Saudi Arabia: Culture and the Acceptance and Use of IT. Information \& Management, 44, 681-691.

Al-Qirim, N. (2007). The adoption of eCommerce communications and applications technologies in small businesses in New Zealand. Electronic Commerce Research and Applications, 6, 462-473.

Anderson, J.C., \& Gerbing, D.W. (1988). Structural equation modelling in practice: A review and recommended two-step approach. Psychological Bulletin, 103, 411-423.

Bagozzi, R.P., \& Yi, Y. (1988). On the evaluation of structural equation models. Journal of the Academy of Marketing Science, 16, 74-94.

Bartl, M, Fuller, J., Muhlbaccher, H., \& Ernst, H. (2012). A manager's perspective on virtual customer integration for new product development. Journal of Product Innovation Management, 29, 1031-1046.

Boyd, D. M., \& Ellison, N. B. (2008). Social network sites: Definition, history and scholarship. Journal of Computer-Mediated Communication, 13, 210-230.

Buhalis, D., \& Law, R. (2008). Progress in information technology and tourism management: 20 years on and 10 years after the Internet - The state of eTourism research. Tourism Management, 29, 609-623. 
Celuch, K., \& Murphy, G. (2010). SME Internet use and strategic flexibility: The moderating effect of IT market orientation. Journal of Marketing Management, 26, 131-145.

Chen, C.F., \& Myagmarsuren, O. (2013). Exploring the moderating effects of value offerings between market orientation and performance in tourism industry. International Journal of Tourism Research, 15, 595-610.

Chen, Y-L., Tang, K., Wu, C.C., \& Jheng, R.Y. (2014). Predicting the influence of users' posted information for eWOM advertising in social networks. Electronic Commerce Research and Applications, 13, 431-439.

Compeau, D.R., \& Higgings, C.A. (1995). Computer self-efficacy: Development of a measure and initial test. MIS Quarterly, 19, 189-211.

D’Ambra, J., Rice, R.E., \& O'Connor, M. (1998). Computer-mediated communication and media preference: An investigation of the dimensionality of perceived task equivocality and media richness. Behaviour and Information Technology, 17, 164-174.

Eckhardt, A., Laumer, S., \& Weitzel, T. (2009). Who influences whom? Analyzing workplace referents' social influence on its adoption and non-adoption. Journal of Information Technology, 24, 11-24.

Escobar-Rodríguez, T., \& Carvajal-Trujillo, E. (2014). Online purchasing tickets for low cost carriers: An application of the unified theory of acceptance and use of technology (UTAUT) model. Tourism Management, 43, 70-88.

European Commission (2003). Commission Recommendation of 6 May 2003 concerning the definition of micro, small and medium-sized enterprises. Official Journal of the European Union, 36-41.

Fang, Y-H. (2014). Beyond the credibility of electronic word of mouth: Exploring eWOM adoption on social networking sites from affective and curiosity perspectives. International Journal of Electronic Commerce, 18, 67-102. 
Fernandes, S., Belo, A., \& Castela, G. (2016). Social network enterprise behaviors and patterns in SMEs: Lessons from a Portuguese local community centered around the tourism industry. Technology in Society, 44, 15-22.

Fornell, C., \& Larcker, D. F. (1981). Evaluating structural equation models with unobservable variables and measurement error. Journal of Marketing Research, 18, 39-50.

Fu, J-R., Ju, P-H., \& Hsu, C.W. (2015). Understanding why consumers engage in electronic word-of-mouth communication: Perspectives from Theory of Planned Behavior and Justice Theory. Electronic Commerce Research and Applications, 14(6), 616-630.

Fundetec (2015). Análisis sectorial de implantación de las TIC en la pyme Española. Informe ePyme 14. Available: http://www.ipyme.org.

Grinstein, A. (2008a). The effect of market orientation and its components on innovation consequences: A meta-analysis. Journal of the Academy of Marketing Science, 36, 166173.

Grinstein, A. (2008b). The relationships between market orientation and alternative strategic orientations. A meta-analysis. European Journal of Marketing, 42, 115-134.

Hair, J.F. Anderson, R.E., Tatham, R.L., \& Black, W.C. (2010). Multivariate data analysis, 7th edition. New Jersey: Prentice Hall,.

Herrero, A., Collado, J., \& García de los Salmones, M.M. (2013). Market Orientation and Manager's Innovativeness in the Adoption of Managerial IT in Small Firms: Application to the Retail Sector. The International Journal of Human Capital and Information Technology Professionals (IJHCITP), 4(3), 58-75.

Herrero, A.; San Martín, H., \& Hernández, J.M. (2015). How online search behavior is influenced by user-generated content on review websites and hotel interactive websites. International Journal of Contemporary Hospitality Management, 27, 1573-1597.

Hofacker, C.F., \& Belanche, D. (2016). Eight social media challenges for marketing managers. Spanish Journal of Marketing - ESIC, 20, 73-80. 
Hult, G.T.M., Hurley, R.F., \& Knight, G.A. (2004). Innovativeness: its antecedents and impact on business on business performance. Industrial Marketing Management, 33, 429-438.

Jímenez-Jiménez, D., Sanz-Valle, R., \& Hernández-Espallardo, M. (2008). Fostering innovation. The role of market orientation and organizational learning. European Journal of Innovation Management, 11, 389-412.

Jaworski, B.J., \& Kohli, A.K. (1993). Market orientation - Antecedents and consequences. Journal of Marketing, 57, 53-70.

Kohli, A., \& Jaworski, B. (1990). Market orientation: The construct, research propositions and managerial implications. Journal of Marketing, 54, 1-18.

Kotler, P., Kartajaya, H., \& Setiawan, I. (2016). Marketing 4.0: Moving from Traditional to Digital. John Wiley \& Sons Inc.

Kwok, L., \& Yu, B. (2013). Spreading social media messages on Facebook: An analysis of restaurant business-to-consumer communications. Cornell Hospitality Quarterly, 54, 84-94.

Law, R., Buhalis, D., \& Cobanoglu, C. (2014). Progress on information and communication technologies inhospitality and tourism. International Journal of Contemporary HospitalityManagement, 26, 727-750.

Lee, J., \& Runge, J. (2001). Adoption of information technology in small business: Testing drivers of adoption for entrepreneurs. Journal of Computer Information Systems, 42, 44-57.

Lee, S-Y.T., \& Phang, C.W (2015). Leveraging social media for electronic commerce in Asia: Research areas and opportunities. Electronic Commerce Research and Applications, 14, 145-149.

Leung, D., Law, R., van Hoof, H., \& Buhalis, D. (2013). Social Media in Tourism and Hospitality: A Literature Review. Journal of Travel \& Tourism Marketing, 30, 3-22. 
Lu, J., Yao, J.E., \& Yu, C-S. (2005). Personal innovativeness, social influences and adoption of wireless Internet services via mobile technology. Journal of Strategic Information Systems, 14, 245-268.

McDonald, R. P., \& Ho, M-H. R. (2002). Principles and Practice in Reporting Structural Equation Analyses. Psychological Methods, 7, 64-82.

Martins, J., Gonçalves, R., Pereira, J., Oliveira, T., \& Pérez, M. (2014). Social networks sites adoption at firm level: A literature review. Information Systems and Technologies (CISTI), 7th Iberian Conference, 1-6.

Moore, G.C., \& Benbasat, I. (1991). Development of an instrument to measure the perceptions of adopting an information technology innovation. Information Systems Research, 2, 192-222.

Narver, J.C., \& Slater, F.S. (1990). The effect of a market orientation on business profitability. Journal of Marketing, 54, 20-35.

Nguyen, T.D., \& Barrett, N.J. (2007). Internet-based knowledge internalization and firm internationalization in transition markets. Advances in International Marketing, 17, 36994.

Nunally, J.C. (1978). Psychometric theory, 2nd Edition. New York: McGraw Hill.

Palacios-Marques, D., Merigo, J.M., \& Soto-Acosta, P. (2015). Online social networks as an enabler of innovation in organizations. Management Decision, 53, 1906-1920.

Parveen, F., Jaafar, N.I., \& Ainin, S. (2015). Social media usage and organizational performance: Reflections of Malaysian social media managers. Telematics and Informatics, 32, 67-78.

Poba-Nzaou, P., Lemieuxa, N., Beaupré, D., \& Uwizeyemungu, S. (2016). Critical challenges associated with the adoption of socialmedia: A Delphi of a panel of Canadian human resources managers. Journal of Business Research, 69, 4010-4019. 
Polo, A.I., Frias, D., \& Rodriguez, M.A. (2011). Impact of Market Orientation and ICT on the Performance of Rural Smaller Service Enterprises. Journal of Small Business Management, 49, 331-360.

Polo, A.I., Frías, D., \& Rodriguez, M.A. (2013). Impact of Customer Orientation and ICT Use on the Perceived Performance of Rural Tourism Enterprises. Journal of Travel \& Tourism Marketing, 30, 272-289.

Redshift Research (2013). Facebook Guía la Elección de Destino de Vacaciones del 87\% de los Jóvenes. Available: www.hosteltur.com/121020 facebook-guia-eleccion-destinovacaciones-87-jovenes.html.

San Martín, H., \& Herrero, A. (2012). Influence of the user's psychological characteristics on the online purchase of rural accommodation: Integrating innovativeness to the UTAUT framework. Tourism Management, 33, 341-350.

Statista (2016). Social Media \& User-Generated Content. Global social networks ranked by number of users. Available online: http://www.statista.com/statistics/272014/globalsocial-networks-ranked-by-number-of-users/.

Steenkamp, J.E.M., \& Van Trijp, H.C.M. (1991). The use of Lisrel in validating marketing constructs. International Journal of Research in Marketing, 8, 283-299.

Sykes, T.A., Venkatesh, V., \& Gosain, S. (2009). Model of acceptance with peer support: A social network perspective to understand employees' system use. MIS Quarterly, 33, 371-393.

Taylor, S., \& Todd, P.A. (1995). Understanding information technology usage: A test of competing models. Information Systems Research, 6, 144-176.

Tsiotsou, R.H., \& Vlachopoulou, M. (2011). Understanding the effects of market orientation and e-marketing on service performance. Marketing Intelligence \& Planning, 29, 141155. 
Van Osch, W., \& Coursaris, C.K. (2014). Social Media Research: An assessment of the domain's productivity and intellectual evolution. Communication Monographs, 81, 285309.

Van Raaij, E.M., \& Schepers, J.J.L. (2008). The acceptance and use of a virtual learning environment in China. Computers \& Education, 50, 838-852.

Venkatesh, V., Morris, M.G., Davis, G.B., \& Davis, F.D. (2003). User acceptance of information technology: Toward a unified view. MIS Quarterly, 27, 425-478.

Venkatesh, V., Thong, J.Y.L., \& Xu, X. (2012). Consumer acceptance and use of information technology: Extending the Unified Theory of Acceptance and Use of Technology. MIS Quarterly, 36, 157-178.

Verhees, F., \& Meulenberg, M. (2004). Market orientation, innovativeness, product innovationand performance in small firms. Journal of Small Business Management, 42, $134-154$.

Wang H-W., \& Wang, S-H. (2010). User acceptance of mobile internet based on the unified theory of acceptance and use of technology: Investigating the determinants and gender differences. Social Behavior \& Personality: An International Journal, 33, 415-426.

Wang, Y-S., Wu, M-C., \& Wang H-Y. (2009). Investigating the determinants and age and gender differences in the acceptance of mobile learning. British Journal of Educational Technology, 40, 92-118.

Xiang, Z., \& Gretzel, U. (2010). Role of Social Media in Online Travel Information Search. Tourism Management, 31, 179-188. 
Table 1. Profile of firms and respondents

\begin{tabular}{|c|c|c|c|}
\hline Microenterprise characteristics & $\%$ & Respondent characteristics & $\%$ \\
\hline Number of employees & & Managerial role & \\
\hline Individual entrepreneur & 54.0 & Owner & 68.5 \\
\hline 2 to 4 employees & 32.5 & Manager & 31.5 \\
\hline 5 to 9 employees & 13.5 & Gender & \\
\hline Annual income & & Man & 54.5 \\
\hline Less than $100,000 €$ & 75.3 & Woman & 45.5 \\
\hline 100,001 to $200,000 €$ & 15.9 & Age & \\
\hline 200,001 to $500,000 €$ & 7.6 & 26 to 35 year & 11.5 \\
\hline 500,001 to 2 million $€$ & 1.2 & 36 to 45 year & 28.0 \\
\hline Type of microenterprise & & 46 to 55 year & 40.5 \\
\hline Hotels & 16.5 & 55 year or more & 20.0 \\
\hline Hostels/bed \& breakfasts & 10.0 & Education level & \\
\hline Tourist apartments & 11.0 & No studies & 0.5 \\
\hline Camping sites & 1.5 & Primary & 14.5 \\
\hline \multirow[t]{2}{*}{ Rural tourism accommodation } & 61.0 & Secondary & 45.5 \\
\hline & & College/postgraduate & 39.5 \\
\hline
\end{tabular}


Table 2. Descriptive statistics

\begin{tabular}{|c|c|c|c|c|c|}
\hline Factor & Variable & Mean & Standard deviation & Skewness & Kurtosis \\
\hline \multirow{4}{*}{ Customer orientation (CUO) } & CUO1 & 7.9 & 2.2 & -1.2 & 1.0 \\
\cline { 2 - 6 } & CUO2 & 7.7 & 2.4 & -0.8 & 0.0 \\
\cline { 2 - 6 } & CUO3 & 8.0 & 2.0 & -0.8 & 0.0 \\
\cline { 2 - 6 } & CUO4 & 8.2 & 1.9 & -0.9 & 0.0 \\
\hline \multirow{5}{*}{ Competitor orientation (COO) } & COO1 & 6.1 & 2.7 & -0.3 & -0.8 \\
\cline { 2 - 6 } & COO2 & 5.7 & 2.7 & -0.1 & -0.8 \\
\cline { 2 - 6 } & COO3 & 5.5 & 2.7 & 0.0 & -0.9 \\
\cline { 2 - 6 } & COO4 & 6.0 & 2.7 & -0.2 & -0.7 \\
\hline \multirow{5}{*}{ Effort expectancy (EE) } & PE1 & 7.3 & 2.7 & -0.6 & -0.8 \\
\cline { 2 - 6 } & PE2 & 7.4 & 2.6 & -0.7 & -0.5 \\
\cline { 2 - 6 } & PE3 & 7.1 & 2.8 & -0.5 & -1.0 \\
\cline { 2 - 6 } & PE4 & 7.2 & 2.7 & -0.5 & -0.9 \\
\hline & EE1 & 6.1 & 2.7 & -0.2 & -0.9 \\
\cline { 2 - 6 } & EE2 & 5.7 & 2.8 & -0.1 & -1.0 \\
\cline { 2 - 6 } & EE3 & 5.8 & 2.8 & 0.0 & -1.0 \\
\cline { 2 - 6 } Social influence (SI) & EE4 & 5.2 & 2.9 & 0.2 & -1.0 \\
\hline & SI1 & 7.5 & 2.5 & -0.7 & -0.3 \\
\cline { 2 - 6 } & SI2 & 7.4 & 2.5 & -0.7 & -0.4 \\
\cline { 2 - 6 } & SI3 & 7.4 & 2.5 & -0.6 & -0.6 \\
\hline \multirow{3}{*}{ Facilitating conditions (FC) } & FC1 & 6.8 & 2.7 & -0.5 & -0.7 \\
\cline { 2 - 6 } & FC2 & 6.0 & 2.8 & -0.1 & -1.0 \\
\cline { 2 - 6 } & FC3 & 6.0 & 2.8 & -0.1 & -1.0 \\
\cline { 2 - 6 } & FC4 & 6.2 & 2.7 & -0.2 & -0.9 \\
\hline \multirow{3}{*}{ Intention to use SNS (INT) } & INT1 & 7.9 & 2.8 & -1.1 & 0.2 \\
\cline { 2 - 6 } & INT2 & 7.5 & 3.0 & -1.0 & -0.4 \\
\cline { 2 - 6 } & INT3 & 7.9 & 2.8 & -1.2 & 0.2 \\
\hline & & & & & \\
\hline
\end{tabular}


Table 3. Confirmatory factor analysis

\begin{tabular}{|c|c|c|c|c|c|c|c|}
\hline Factor & Variable & $\begin{array}{l}\text { Standard } \\
\text { Coefficient }\end{array}$ & $\mathrm{R}^{2}$ & $\begin{array}{l}\text { Cronbach's } \\
\text { alpha }\end{array}$ & $\begin{array}{l}\text { Composite } \\
\text { Reliability }\end{array}$ & AVE & $\begin{array}{r}\text { Goodness of fit } \\
\text { indexes }\end{array}$ \\
\hline \multirow{4}{*}{$\begin{array}{l}\text { Customer } \\
\text { orientation } \\
\text { (CUO) }\end{array}$} & CUO1 & 0.62 & 0.39 & \multirow{4}{*}{0.88} & \multirow{4}{*}{0.89} & \multirow{4}{*}{0.68} & \\
\hline & CUO2 & 0.80 & 0.64 & & & & \\
\hline & CUO3 & 0.93 & 0.86 & & & & \\
\hline & CUO4 & 0.90 & 0.81 & & & & \\
\hline \multirow{4}{*}{$\begin{array}{l}\text { Competitor } \\
\text { orientation } \\
(\mathrm{COO})\end{array}$} & $\mathrm{COO} 1$ & 0.92 & 0.85 & \multirow{4}{*}{0.96} & \multirow{4}{*}{0.96} & \multirow{4}{*}{0.86} & \\
\hline & $\mathrm{COO} 2$ & 0.92 & 0.85 & & & & \\
\hline & $\mathrm{COO} 3$ & 0.94 & 0.88 & & & & \\
\hline & $\mathrm{COO} 4$ & 0.92 & 0.86 & & & & \\
\hline \multirow{4}{*}{$\begin{array}{l}\text { Performance } \\
\text { expectancy } \\
\text { (PE) }\end{array}$} & PE1 & 0.97 & 0.94 & \multirow{4}{*}{0.97} & \multirow{4}{*}{0.97} & \multirow{4}{*}{0.89} & \\
\hline & PE2 & 0.98 & 0.96 & & & & \\
\hline & PE3 & 0.93 & 0.88 & & & & Normed $\chi^{2}=2.11$ \\
\hline & PE4 & 0.90 & 0.81 & & & & $\mathrm{BBNFI}=0.91$ \\
\hline \multirow{4}{*}{$\begin{array}{l}\text { Effort } \\
\text { expectancy } \\
\text { (EE) }\end{array}$} & EE1 & 0.95 & 0.90 & \multirow{4}{*}{0.94} & \multirow{4}{*}{0.95} & \multirow{4}{*}{0.82} & $\mathrm{BBNNFI}=0.94$ \\
\hline & EE2 & 0.93 & 0.87 & & & & $\mathrm{CFI}=0.95$ \\
\hline & $\begin{array}{l}\text { LE2 } \\
\text { EE3 }\end{array}$ & 0.98 & 0.96 & & & & $\mathrm{IFI}=0.95$ \\
\hline & EE4 & 0.75 & 0.56 & & & & $\mathrm{RMSEA}=0.08$ \\
\hline Social & SI1 & 0.95 & 0.90 & \multirow{3}{*}{0.96} & \multirow{3}{*}{0.96} & \multirow{3}{*}{0.89} & \\
\hline influence & SI2 & 0.99 & 0.98 & & & & \\
\hline$(\mathrm{SI})$ & SI3 & 0.89 & 0.80 & & & & \\
\hline \multirow{4}{*}{$\begin{array}{l}\text { Facilitating } \\
\text { conditions } \\
\text { (FC) }\end{array}$} & $\mathrm{FC} 1$ & 0.66 & 0.43 & \multirow{4}{*}{0.90} & \multirow{4}{*}{0.90} & \multirow{4}{*}{0.70} & \\
\hline & $\mathrm{FC} 2$ & 0.88 & 0.77 & & & & \\
\hline & $\mathrm{FC} 3$ & 0.92 & 0.85 & & & & \\
\hline & FC4 & 0.87 & 0.76 & & & & \\
\hline Intention to & INT1 & 0.93 & 0.87 & \multirow{3}{*}{0.93} & \multirow{3}{*}{0.93} & \multirow{3}{*}{0.82} & \\
\hline use SNS & INT2 & 0.88 & 0.77 & & & & \\
\hline (INT) & INT3 & 0.90 & 0.81 & & & & \\
\hline
\end{tabular}


Table 4. Squared correlation between pairs of latent variables

\begin{tabular}{|c|c|c|c|c|c|c|}
\hline & $\begin{array}{l}\text { Customer } \\
\text { orientation }\end{array}$ & $\begin{array}{l}\text { Competitor } \\
\text { orientation }\end{array}$ & $\begin{array}{l}\text { Performance } \\
\text { expectancy }\end{array}$ & $\begin{array}{l}\text { Effort } \\
\text { expectancy }\end{array}$ & $\begin{array}{l}\text { Social } \\
\text { influence }\end{array}$ & $\begin{array}{l}\text { Facilitating } \\
\text { conditions }\end{array}$ \\
\hline $\begin{array}{l}\text { Competitor } \\
\text { orientation }\end{array}$ & 0.102 & & & & & \\
\hline $\begin{array}{l}\text { Performance } \\
\text { expectancy }\end{array}$ & 0.048 & 0.026 & & & & \\
\hline $\begin{array}{l}\text { Effort } \\
\text { expectancy }\end{array}$ & 0.032 & 0.168 & 0.176 & & & \\
\hline $\begin{array}{l}\text { Social } \\
\text { influence }\end{array}$ & 0.084 & 0.053 & 0.518 & 0.130 & & \\
\hline $\begin{array}{l}\text { Facilitating } \\
\text { conditions }\end{array}$ & 0.044 & 0.144 & 0.230 & 0.828 & 0.194 & \\
\hline $\begin{array}{l}\text { Intention to } \\
\text { use SNS }\end{array}$ & 0.040 & 0.073 & 0.504 & 0.250 & 0.436 & 0.270 \\
\hline
\end{tabular}


Figure 1. Theoretical model

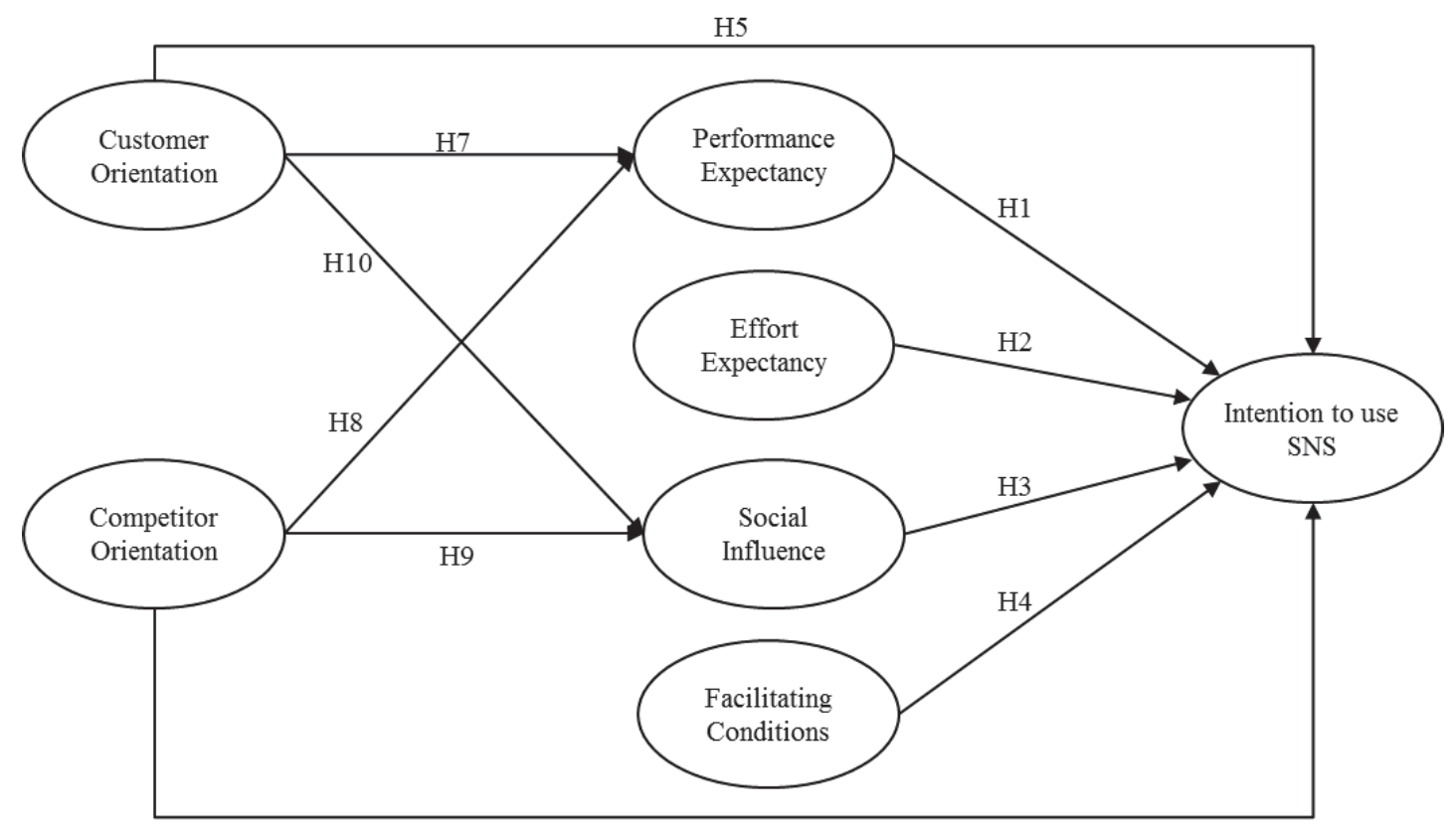

H6 
Figure 2. Estimation of the re-specified model

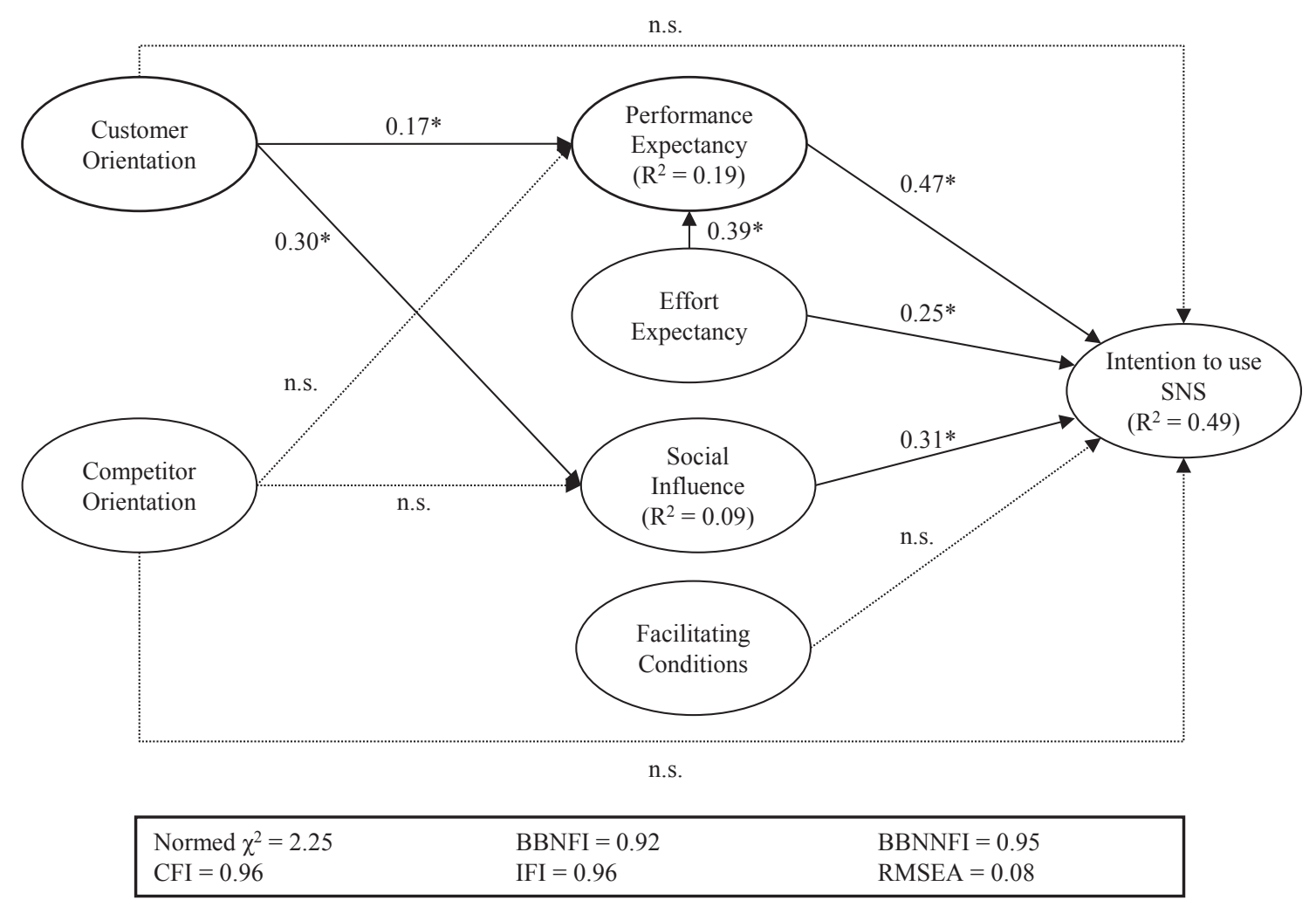




\begin{tabular}{|c|c|c|c|c|c|c|c|c|c|c|c|c|}
\hline & 壳 & & & & & & & & & & & \\
\hline & है & & & & & & & & & & & 용 \\
\hline & : & & & & & & & & & & & 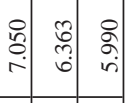 \\
\hline & 音 & & & & & & & & & & & 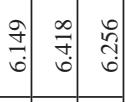 \\
\hline & 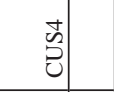 & & & & & & & & & & 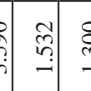 & 部 \\
\hline & $\frac{8}{8}$ & & & & & & & & & & : & : 욤 \\
\hline & : & & & & & & & & & & 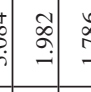 & 常 \\
\hline & $\overline{\mathrm{s}}$ & & & & & & & & & & $\stackrel{0}{0}$ & 侢 \\
\hline & 8 & & & & & & & & : & $\bar{g}$ & 常 & 5 \\
\hline & : & & & & & & & : & : & 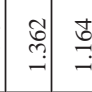 & 苞 &  \\
\hline & $\overline{\bar{o}}$ & & & & & & & $\frac{1}{2}$ & 声 & $\overline{\mathrm{g}}$ & 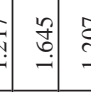 & 웡 월 \\
\hline & $\stackrel{t}{\tilde{x}}$ & & & & & & 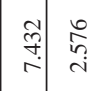 & 营 & : & & 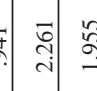 & 楁 \\
\hline & 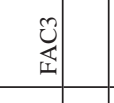 & & & & & & : & $\stackrel{\circ}{\circ}$ & 产 & & 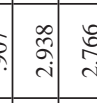 & 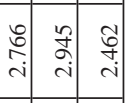 \\
\hline & : & & & & & 売高 &  & 离 & : & $\stackrel{\infty}{\infty}$ & 我 & 新新 \\
\hline & $\overline{\underline{a}}$ & & & & & 就: & $\begin{array}{l}9 \\
7\end{array}$ & : & 表吉 & 8 & 玨 & E: \\
\hline & 苇 & & & & & 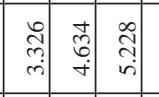 &  &  & 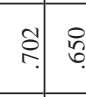 & $\approx$ & 8 & : \\
\hline & : & & & & 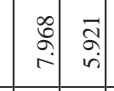 & 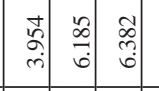 &  & कृ कृ & $\frac{2}{2}$ &  & 告 & 宩 \\
\hline & 돌 & & & & 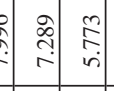 & 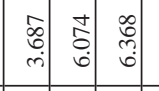 & 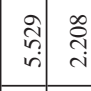 &  & $\bar{g}$ & 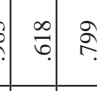 & 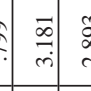 &  \\
\hline & 缟 & & & 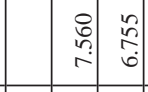 & 종 & 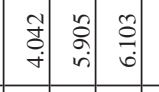 & 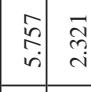 & : & 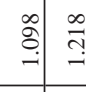 &  & : & 串 \\
\hline & 䓂 & & & 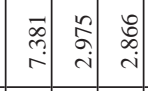 & 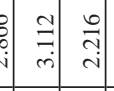 & 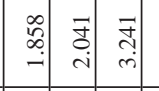 & $\frac{8}{0}=\frac{0}{7}$ & : & $\frac{\circ}{0}$ & 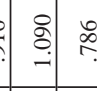 &  & $\bar{a}$ \\
\hline & 畄 & & & : & : & : & $\frac{n}{a}$ & 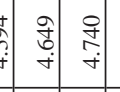 &  & 8 & 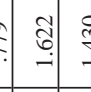 & 㱐 \\
\hline & 䇏 & & 孚总 & : & $\begin{array}{ccc}0 \\
0\end{array}$ & 졸 & $\begin{array}{ll}0 \\
\vdots \\
0\end{array}$ & 语 & & & 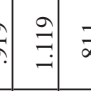 & $\overline{\bar{\alpha}}=\frac{\mathrm{z}}{\mathrm{V}} \mathrm{g}$ \\
\hline & 部 & & 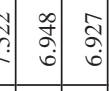 & 表部: &  & $\frac{5}{\pi} \frac{5}{\pi}$ &  & 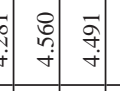 & : & 홍 &  &  \\
\hline & $\frac{\pi}{z}$ & 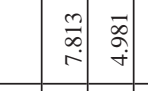 & $\frac{1}{0}$ &  & id & 壱善 & 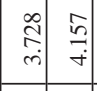 & : & & 列 & $\left(\begin{array}{l}0 \\
\vdots \\
\hdashline\end{array}\right.$ & $\underset{v}{0}$ \\
\hline & $\underline{\tilde{n}}$ & 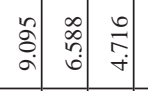 & 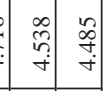 & 点 & ส్లి & 番高 &  & 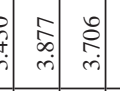 & : & 9 & 8 & 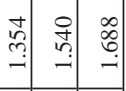 \\
\hline & 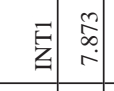 & $\begin{array}{l}0 \\
0\end{array}$ & $\frac{\infty}{a} \frac{7}{q}$ & 象 & : & 密: & 总表学 &  & 表 & 党: & $\left(\begin{array}{l}0 \\
:\end{array}\right.$ & 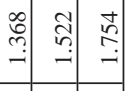 \\
\hline & & $\underline{\underline{z}} \bar{z}$ & & 部㯺 & 䀠 & 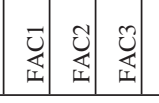 & 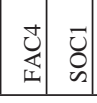 & : & $\overline{3}$ & है & & \\
\hline
\end{tabular}

